Free for All 
CALIFORNIA STUDIES IN FOOD AND CULTURE

Darra Goldstein, Editor 


\section{FREE FOR ALL}

FIXING SCHOOL FOOD IN AMERICA

Janet Poppendieck

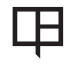

UNIVERSITY OF CALIFORNIA PRESS

Berkeley Los Angeles London 
University of California Press, one of the most distinguished university presses in the United States, enriches lives around the world by advancing scholarship in the humanities, social sciences, and natural sciences. Its activities are supported by the UC Press Foundation and by philanthropic contributions from individuals and institutions. For more information, visit www.ucpress.edu.

University of California Press

Berkeley and Los Angeles, California

University of California Press, Ltd.

London, England

(C) 20 Io by The Regents of the University of California

Library of Congress Cataloging-in-Publication Data

Poppendieck, Janet, I945-.

Free for all : fixing school food in America / Janet

Poppendieck.

p. cm. - (California studies in food and culture; 28)

Includes bibliographical references and index.

ISBN 978-0-520-24370-5 (cloth : alk. paper)

I. National school lunch program. 2. School breakfast programs-United States. 3. School children-

Food-United States. 4. Children-Nutrition-United States. I. Title. II. Title: Fixing school food in America.

LB3479.U6P5 52010

37 I.7'I60973-dc22

2009015369

Manufactured in the United States of America

I9 I 8 I7 76 I5 5 I4 I3 $\begin{array}{lllll} & \text { I2 } & \text { II } & \text { IO }\end{array}$

$\begin{array}{llllllllll}\text { IO } & 9 & 8 & 7 & 6 & 5 & 4 & 3 & 2 & \text { I }\end{array}$

This book is printed on Cascades Enviro Io0, a Io०\% post consumer waste, recycled, de-inked fiber. FSC recycled certified and processed chlorine free. It is acid free, Ecologo certified, and manufactured by BioGas energy. 
For my daughter, Amanda 
This Page Left Intentionally Blank 